\title{
Protein variation and involvement of insulin-like growth factor during embryonic development in the olive flounder Paralichthys olivaceus
}

\author{
Kang-Woong Kim ${ }^{1}$, Taek Jeong $\mathrm{Nam}^{2}$ and Youn Hee Choi ${ }^{3^{*}}$ (D)
}

\begin{abstract}
Insulin-like growth factors (IGFs), along with IGF-binding protein and IGF receptor, are well-known regulators in the growth and survival of vertebrates. In this study, we investigated the involvement of IGFs and protein variation during embryonic development of the olive flounder (Paralichthys olivaceus). Morphological stages were divided into six main developments as blastula, gastrula, cephalization, cranial regionalization, tail lift, and hatch. During embryonic development, protein variation was investigated using sodium dodecyl sulfate-polyacrylamide gel electrophoresis and electrospray ionization quadrupole time-of-flight mass spectrometry/mass spectrometry. In addition, the mechanism of signaling of IGF-I receptor was examined using immuno-blot analysis. We found marked changes in protein expression at four stages of embryonic development and identified proteins as belonging to the vitellogenin 2 family. As development progresses, expression of IGF-II, phosphotyrosine, and phospho-Akt increased, while expression of growth factor receptor-bound protein 2 (GRB2) and one of guanine-nucleotide-binding proteins (Ras) decreased. These results provide basic information on the IGF system in the embryonic development of the olive flounder.
\end{abstract}

Keywords: Olive flounder, Embryonic development, Insulin-like growth factor, Vitellogenin

\section{Background}

Insulin-like growth factor (IGF) plays important roles in regulating growth, metabolism, development, reproduction, osmoregulation, and the immune response (Li et al. 2012). IGF-I is a growth indicator in fish (Vera Cruz et al. 2006) and induces biological responses with specific receptors in target tissues. In addition, IGF-I and IGF-II play important roles in early embryonic development and growth in mammals and fish (Hardy and Spanos 2002; Chandra et al. 2011). Mammalian embryos require more time for differentiation and growth than do fish embryos, and they depend on various signal pathways generated by growth factors during preimplantation (Riley et al. 2005). In fish, the expression of IGF-I and IGF-II mRNAs depended on the embryonic

\footnotetext{
*Correspondence: unichoi@pknu.ac.kr

${ }^{3}$ Department of Marine Bio-Materials and Aquaculture, Pukyong National University, Busan 48513, Republic of Korea

Full list of author information is available at the end of the article

stage and was detected in different organs and at developmental stages (Xu et al. 2015; Yuan and Hong 2017).

The olive flounder Paralichthys olivaceus is an important economic marine aquaculture fish in Korea. In particular, early seed production, which is controlled by fertilization and hatching rate, is vital for aquaculture success. Therefore, to study the relationships between normal expression of growth factors, such as IGF-I and IGF-II, and normal development and embryo growth of the olive flounder, we investigated the involvement of IGFs and protein variation during embryonic development.

\section{Methods}

Sample preparation

Embryos were obtained from the Korean Fish Breeding Institute, Jeju-Si, Jeju Special Self-Governing Province, Korea. They were maintained in 50-L square tanks ( $n=3$ pools) at $18 \pm 0.5^{\circ} \mathrm{C}$. Samples were collected at the blastula (12 hours 
post-fertilization [hpf]), early gastrula (17 hpf), gastrula (21 hpf), cephalization (22 hpf), early cranial regionalization (27 hpf), late cranial regionalization (34 hpf), and tail lift (42 hpf) stages; stage classification followed Martinez and Bolker (2003) (Fig. 1). Samples $(n=50)$ were immediately frozen in liquid nitrogen and stored at $-75{ }^{\circ} \mathrm{C}$ until use.

\section{Protein sequencing}

We investigated protein changes during embryonic development using sodium dodecyl sulfate-polyacrylamide gel electrophoresis (SDS-PAGE). Specific proteins were confirmed using electrospray ionization quadrupole timeof-flight mass spectrometry/mass spectrometry (ABI, USA), according to a previously described method (Choi et al. 2015). Proteins were identified via the UniProt Knowledgebase (http://www.uniprot.org/uniprot) using the MASCOT program (Matrixscience, London, UK).

\section{Western blot analysis}

To determine IGF involvement in embryo development, an immunoblot assay was performed. Embryos $(n=50)$ were homogenized in radio immunoprecipitation lysis buffer $(50 \mathrm{mM}$ Tris, $1 \mathrm{mM}$ ethylene glycol-bis (2-aminoethylether)- $N, N, N^{\prime}, N^{\prime}$-tetraacetic acid, $150 \mathrm{mM} \mathrm{NaCl}$, $1 \% \mathrm{NP}-40$, and $0.25 \%$ Na-deoxycholate) containing protease inhibitors $\left(1 \mu \mathrm{g} \mathrm{mL} \mathrm{m}^{-1}\right.$ aprotinin, $1 \mu \mathrm{g} \mathrm{mL}$ leupeptin, $1 \mu \mathrm{g} \mathrm{mL} \mathrm{g}^{-1}$ pepstatin, $1 \mathrm{mM} \mathrm{Na}_{3} \mathrm{VO}_{4}, 1 \mathrm{mM}$ $\mathrm{NaF}$, and $1 \mathrm{mM}$ phenylmethanesulfonyl fluoride). Samples were centrifuged at 12,000 rpm for $10 \mathrm{~min}$, and the supernatant was collected. Protein concentration was measured using the BCA Protein Assay Kit (Pierce Biotechnology, Rockford, IL, USA). Proteins (30-50 $\mu \mathrm{g}$ ) were separated by $8-15 \%$ SDS-PAGE and transferred to polyvinyl difluoride membranes (Millipore, Billerica, MA, USA). The membranes were blocked with TBS-T (10 mM Tris- $\mathrm{HCl}, 150 \mathrm{mM} \mathrm{NaCl}[\mathrm{pH}$ 7.5], and $0.1 \%$ Tween 20) containing $1 \%$ bovine serum albumin and incubated with primary antibody (1:1000 in TBS-T) on a rocker overnight at $4{ }^{\circ} \mathrm{C}$. Primary antibodies used for immunoblotting included polyclonal rabbit anti-IGF-I, anti-IGF-II, anti-IGF-IR ß-subunit, anti-RAS, anti-GRB2, anti-p-AKT1/2/3, anti-mitogen-activated protein kinase kinase (MEK), monoclonal mouse p-Tyr (PY99), antiextracellular signal-regulated kinase (ERK) $1 / 2$, and antip-ERK (Santa Cruz Biotechnology, Santa Cruz, CA, USA). After washing in TBS-T, membranes were incubated for $1 \mathrm{~h}$ at room temperature with horseradish peroxidase (HRP)-conjugated goat anti-mouse immunoglobulin G (IgG, sc-2031; Santa Cruz Biotechnology) or HRP-conjugated goat anti-rabbit IgG (A-0545; SigmaAldrich, St. Louis, MO, USA) diluted 1:10,000 in TBS-T. Monoclonal mouse anti- $\beta$-actin (C4) antibody (sc-47778; Santa Cruz Biotechnology) was used as a control. Protein was detected using enhanced chemiluminescence detection reagents (Advansta, Menlo Park, CA, USA) and visualized using the GeneSys imaging system (SynGene Synoptics, Ltd., London, UK).

\section{Statistical analysis}

Data were evaluated statistically using one-way analysis of variance (Statistical Package for the Social Sciences, ver. 10.0; SPSS Inc., Chicago, IL, USA). Significant differences between means were tested using Duncan's multiple range test $(p<.05)$.

\section{Results}

Protein variation

Protein expression depended on embryonic stage, and marked variations in protein expression were detected at four stages (Fig. 2, arrows). These proteins were identified as belonging to the vitellogenin 2 family (Accession no.: $\operatorname{tr} \mid \mathrm{Q} 5 \mathrm{KQQ}$ 7|Q5KQQ7_PAROL, http://www.uniprot.org/uniprot/Q5KQQ7) by comparing its probable
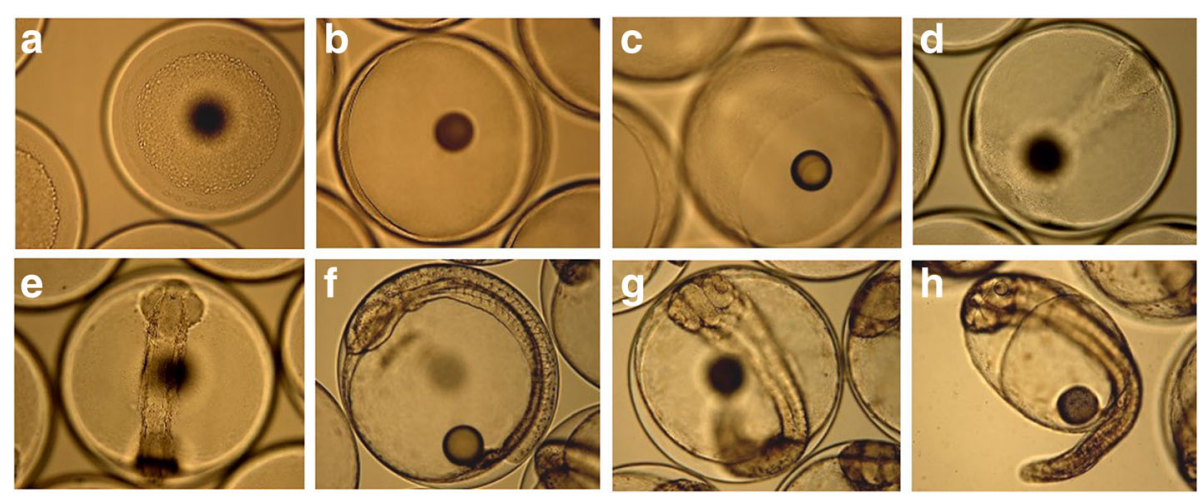

Fig. 1 Development of eggs and hatched larvae of the olive flounder (Paralichthys olivaceus). Developmental stages: a blastula, b early gastrula, c late gastrula, $\mathbf{d}$ cephalization, e early cranial regionalization, $\mathbf{f}$ late cranial regionalization, $\mathbf{g}$ tail lift, and $\mathbf{h}$ hatched larva $(\times 100)$ 


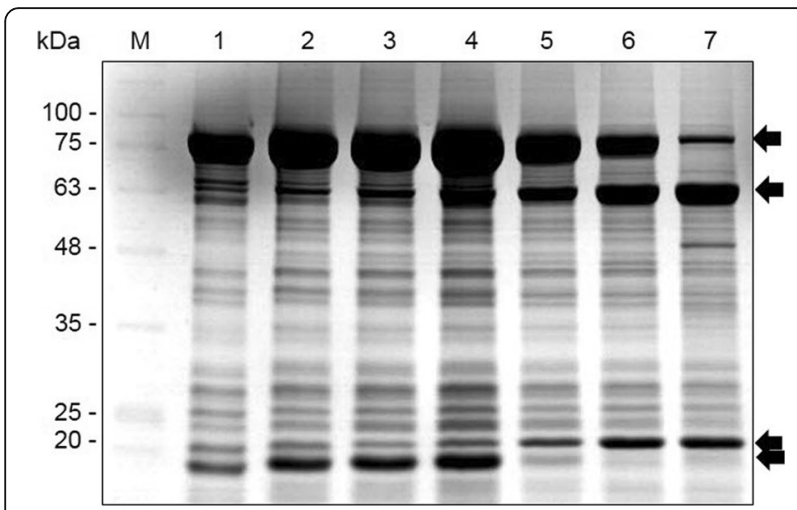

Fig. 2 Changes in protein during development in the olive flounder ( $P$. olivaceus). The four arrows indicate the vitellogenin 2 family. $M$, marker; 1 , blastula; 2, early gastrula; 3, late gastrula; 4, cephalization; 5, early cranial regionalization; 6, late cranial regionalization; 7, tail lift

amino acid sequence with those in the NCBI and UniProt protein databases.

\section{Expression of IGF-IR-related proteins}

In this study, the IGF-IR $\beta$-subunit was not detected in all developmental stages. To determine whether the IGF-IR $\beta$-subunit was activated, tyrosine phosphorylation (PY99) was assessed using immunoblot analysis. Expression of PY99 throughout egg development was observed. IGF-II expression increased significantly as egg development progressed (Fig. 3a). These results suggest that binding of IGF-II to IGF-IR stimulates egg development. Docking of GRB2 to the phosphorylated IGF-IR $\beta$-subunit leads to ERK phosphorylation through the Ras/MEK axis (Fig. 3b). The expression of p-Akt increased during development (Fig. 3b).

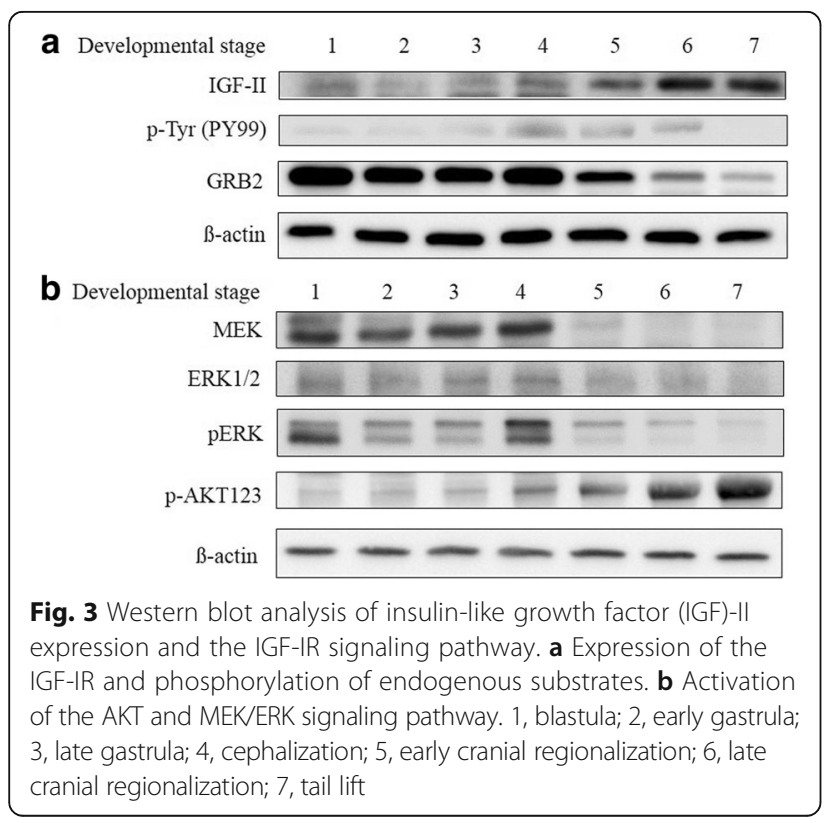

\section{Discussion}

IGF signaling has been proposed to be a major factor in the growth and development of vertebrates (Duan and $\mathrm{Xu}$ 2005; Schlueter et al. 2007). The effects of IGFs on embryonic growth and development in fish have been examined in zebrafish (Schlueter et al. 2007; Zou et al. 2009) and rainbow trout (Li et al. 2010). Normal embryonic development and growth depend on a combination of internal and aqua-environmental factors (Choi and Chang 2003). The embryo is free floating, with no direct cell-to-cell contact, lacks a blood supply, and is exposed to a dynamic fluid environment (Hardy and Spanos, 2002; Riley et al. 2005). Therefore, the embryo depends on autocrine and paracrine growth factors to support its growth and development (Riley et al. 2005). The IGF-IGF receptor-IGF-binding protein system is a complex regulatory system that is essential for normal growth and development (Duan, 1997), and autocrine/ paracrine IGF-I is the main determinant of postnatal body growth (Ohlsson et al., 2000). Also, the structure of the fish IGF-IR is very similar to that of mammals with an overall amino acid sequence identity of $72 \%$ (Duan 1997). These findings indicate that the IGF-IR is highly conserved both structurally and functionally in teleost fish (Choi et al. 2014). IGF-IR mediates IGF-I and IGF-II action in prenatal growth, and IGF-II action in postnatal growth, in mammals (Santos et al. 2008). Autocrine/paracrine roles of IGF-II in the differentiation, maintenance, and regeneration of central neurons and in the maturation of oocytes and follicle development in fish have been reported (Caelers et al. 2004). In this study, the expression of phosphotyrosine was examined, and IGF-II was found to be expressed after the cephalization stage, leading to the differentiation of such organs as the optic vesicles. IGF-IR activation leads to downstream activation of the RAS/MEK/ERK pathway and the Akt pathway. RAS/MEK/ERK is a key signaling pathway in cell proliferation and differentiation (Fuentes et al. 2011). Akt activation modulates the function of numerous downstream substrates involved in the regulation of cell survival and growth (Manning and Cantley 2007). In the present study, promotion of embryo growth occurred through the activation of ERK and Akt.

The expression of IGF-IR-related signaling is associated with changes in the expression of the vitellogenin 2 family. Oviparous teleost eggs accumulate a large amount of yolk protein as a nutrient store required by developing embryos (Matsubara et al. 1999). During vitellogenesis, yolk precursor proteins (vitellogenin [Vg]) are synthesized hepatically and regulated by estrogen (Matsubara et al. 1999). The presence of two types of $\mathrm{Vg}$ molecule ( Vg A and Vg B) was reported in the barfin flounder, and these molecules function during oocyte maturation and embryonic development (Matsubara et 
al. 1999). In this study, changes in vitellogenin 2 family expression were observed during embryonic development. The molecular weights of native $\mathrm{Vg}$ were estimated to be 550,000 in Platichthys flesus (Emmersen and Petersen 1976) and 530,000 in Scophthalmus maximus (Silversand and Haux 1989). In this study, higher-molecular-weight Vgs may have degraded over time and become involved in embryonic development. Further studies regarding the association between the function of cleaved Vgs and embryonic developments are necessary.

\section{Conclusions}

IGF-II and IGF-IR are expressed during embryonic development and are associated with the IGF-IR signaling pathway. The IGF signaling cascade may be involved in developmental regulation. Further study is needed to determine the relationship between $\mathrm{Vg}$ and the IGF system during embryonic development of the olive flounder.

\section{Abbreviations}

ERK 1/2: Extracellular signal-regulated kinase 1/2; GRB2: Growth factor receptor-bound protein 2; Hpf: Hours post-fertilization; HRP: Horseradish peroxidase; IGFs: Insulin-like growth factors; MEK: Mitogen-activated protein kinase kinase; SDS-PAGE: Sodium dodecyl sulfate-polyacrylamide gel electrophoresis; Vg: Vitellogenin

\section{Acknowledgements}

The authors thank the Korean Fish Breeding Institute, Jeju-Si, Jeju Special Self-Governing Province, Korea, for access to olive flounder eggs.

\section{Funding}

This work was supported by a Research Grant of Pukyong National University (year 2016).

\section{Availability of data and materials}

All data sets generated during and/or analyzed during the current study is available from the authors on reasonable request.

\section{Authors' contributions}

All authors conceived and designed the experiments. KWK and YHC performed the experiments. All authors analyzed the data. YHC wrote the paper, and all authors have read and approved the final manuscript.

\section{Ethics approval and consent to participate}

Not applicable

\section{Consent for publication}

Not applicable

\section{Competing interests}

The authors declare that they have no competing interests.

\section{Publisher's Note}

Springer Nature remains neutral with regard to jurisdictional claims in published maps and institutional affiliations.

\section{Author details}

${ }^{1}$ Aquafeed Research Center, National Institute of Fisheries Science, Pohang 37517, Republic of Korea. ${ }^{2}$ Department of Food Science and Nutrition, Pukyong National University, Busan 48513, Republic of Korea. ${ }^{3}$ Department of Marine Bio-Materials and Aquaculture, Pukyong National University, Busan 48513, Republic of Korea.
Received: 22 November 2017 Accepted: 3 January 2018

Published online: 26 February 2018

\section{References}

Caelers A, Berishvili G, Meli ML, Eppler E, Reinecke M. Establishment of a real-time RT-PCR for the determination of absolute amounts of IGF-I and IGF-II gene expression in liver and extrahepatic sites of the tilapia. Gen Comp Endocrinol. 2004;137:196-204.

Chandra V, Kumar GS, Sharma GT. Temporal expression pattern of insulin-like growth factors (IGF-1 and IGF-2) ligands and their receptors (IGF-1R and IGF-2R) in buffalo (Bubalus bubalis) embryos produced in vitro. Live Sci. 2011;135:225-30

Choi YH, Chang YJ. Gametogenic cycle of the transplanted-cultured pearl oyster, Pinctada fucata martensii (Bivalvia: Pteriidae) in Korea. Aquaculture. 2003;220:781-90.

Choi YH, Kim KW, Han HS, Nam TJ, Lee BJ. Dietary Hizikia fusiformis glycoproteininduced IGF-I and IGFBP-3 associated to somatic growth, polyunsaturated fatty acid metabolism, and immunity in juvenile olive flounder Paralichthys olivaceus. Comp Biochem Physiol A. 2014;167:1-6.

Choi YH, Yamaguchi K, Oda T, Nam TJ. Chemical and mass spectrometry characterization of the red alga Pyropia yezoensis chemoprotective protein (PYP): protective activity of the N-terminal fragment of PYP1 against acetaminophen-induced cell death in Chang liver cells. Int J Mol Med. 2015;35:271-6.

Duan C. The insulin-like growth factor system and its biological actions in fish. Amer Zool. 1997;37:491-503.

Duan C, Xu Q. Roles of insulin-like growth factor (IGF) binding proteins in regulating IGF actions. Gen Comp Endocrinol. 2005;142:44-52.

Emmersen BK, Petersen IM. Natural occurrence, and experimental induction by estradiol-17ß, of a lipophosphoprotein (vitellogenin) in flounder (Platichtys flesus, L.). Comp Biochem Physiol. 1976;54B:443-6.

Fuentes EN, Björnsson BT, Valdés JA, Einarsdottir IE, Lorca B, Alvarez M, Molina A. IGF-I/PI3K/Akt and IGF-I/MAPK/ERK pathways in vivo in skeletal muscle are regulated by nutrition and contribute to somatic growth in the fine flounder. Am J Physiol Regul Integr Comp Physiol. 2011;300:R1532-42.

Hardy K, Spanos S. Growth factor expression and function in the human and mouse preimplantaion embryo. J Endocrinol. 2002;172:221-36.

Li M, Bureau DP, King WA, Leatherland JF. The actions of in ovo cortisol on egg fertility, embryo development and the expression of growth-related genes in rainbow trout embryos, and the growth performance of juveniles. Mol Reprod Dev. 2010;77:922-31.

Li Y, Wu S, Ouyang J, Mao L, Li W, Lin H. Expression of insulin-like growth factor1 of orange-spotted grouper (Epinephelus coioides) in yeast Pichia pastoris. Protein Expr Purif. 2012;84:80-5.

Manning BD, Cantley LCAKT. PKB signaling: navigating downstream. Cell. 2007:129:1261-74

Martinez GM, Bolker JA. Embryonic and larval staging of summer flounder (Paralichthys dentatus). J Morphol. 2003:255:162-76.

Matsubara T, Ohkubo N, Andoh T, Sullivan CV, Hara A. Two forms of vitellogenin, yielding two distinct lipovitellins, play different roles during oocyte maturation and early development of barfin flounder, Verasper moseri, a marine teleost that spawns pelagic eggs. Dev Biol. 1999;213:18-32.

Ohlsson C, Sjögren K, Jansson JO, Isaksson OGP. The relative importance of endocrine versus autocrine/paracrine insulin-like growth factor-l in the regulation of body growth. Pediatr Nephrol. 2000;14:541-3.

Riley JK, Carayannopoulos MO, Wyman AH, Chi M, Ratajczak CK, Moley KH. The PI3K/Akt pathway is present and functional in the preimplantation mouse embryo. Dev Biol. 2005;284:377-86.

Santos AN, Ramin N, Tonack S, Fischer B. Cell lineage-specific signaling of insulin and insulin-like growth factor I in rabbit blastocysts. Endocrinol. 2008;149:515-24.

Schlueter PJ, Peng G, Westerfield M, Duan C. Insulin-like growth factor signaling regulates zebrafish embryonic growth and development by promoting cell survival and cell cycle progression. Cell Death Differ. 2007;14:1095-105.

Silversand C, Haux C. Isolation of turbot (Scophthalmus maximus) vitellogenin by high-performance anion-exchange chromatography. J Chromatogr. 1989;478A:387-97.

Vera Cruz EM, Brown CL, Luckenbach JA, Picha ME, Bolivar RB, Borski RJ. Insulin-like growth factor-I cDNA cloning, gene expression and potential use as a growth rate indicator in Nile tilapia, Oreochromis niloticus. Aquaculture. 2006;251:585-95. 
Xu Y, Zang K, Liu X, Shi B, Li C, Shi X. Insulin-like growth factors I and II in starry flounder (Platichthys stellatus): molecular cloning and differential expression during embryonic development. Fish Physiol Biochem. 2015;41:139-52.

Yuan Y, Hong Y. Medaka insulin-like growth factor-2 supports self-renewal of the embryonic stem cell line and blastomeres in vitro. Sci Rep. 2017;7:78. https:// doi.org/10.1038/s41598-017-00094-y.

Zou S, Kamei H, Modi Z, Duan C. Zebrafish IGF genes: gene duplication, conservation and divergence, and novel roles in midline and notochord development. PLoS One. 2009;4:e7026.

Submit your next manuscript to BioMed Central and we will help you at every step:

- We accept pre-submission inquiries

- Our selector tool helps you to find the most relevant journal

- We provide round the clock customer support

- Convenient online submission

- Thorough peer review

- Inclusion in PubMed and all major indexing services

- Maximum visibility for your research

Submit your manuscript at www.biomedcentral.com/submit 